\title{
Microalgae Wastewater Treatment: A Brief History
}

\author{
Matthew B. Paddock ${ }^{a 1^{*}}$
}

aBiological and Agricultural Engineering, University of California, Davis, CA 95616, United States

1ORCHID: 0000-0003-1951-9518

*Corresponding author: Email: mbpaddock@ucdavis.edu

\begin{abstract}
Microalgae wastewater treatment has long been promoted as a sustainable method to handle the influx of human waste due to population growth. Initially, in the early 1900's, microalgae was noted to increase wastewater treatment efficiency by aerating the water and consuming waste. By mid-century, wastewater grown microalgae was being investigated as a way to produce biomass for food, fuel, and other biomaterials. The space race in the 1960's led to the use of microalgae in life support systems. Technological developments and political pressure in the 1970's spurred studies of the impact of wastewater on the growth of phytoplankton in the oceans as well as methods to use microalgae wastewater treatment in aquaculture. Simultaneously, the oil crisis of that decade promoted research of alternative fuels, which included microalgae biofuels via the Aquatic Species Program. This program led to research into the use of wastewater as a feedstock for microalgae growth. By the later 2000's, instability in the oil market caused another energy crisis which further prompted investment in microalgae biofuels, some of which involved combined wastewater treatment. Currently, microalgae wastewater treatment is being researched as a way to cut back on greenhouse gas emissions to curb global warming and produce sustainable biofuels.
\end{abstract}

Keywords: algae, wastewater, microalgae, biofuels, phytoplankton, aquaculture, phycology 


\section{Introduction}

Microalgae has long been recognized as a critical microorganism in wastewater and sewage treatment (Agersborg \& Hatfield, 1929; Cotton, 1910). Early studies of these systems were able to identified that microalgae played an essential role in wastewater treatment: directly through the uptake of organic and inorganic nutrients from waste (Bischoff \& Knauff, 1883; Frankland, 1897) and indirectly through the oxygenation of wastewater for aerobic microbes to further breakdown the waste (Abbott, 1948; Caldwell, 1946; Espinosa, 1948). It wasn't until the mid-1950's that sizable investments were allocated towards understanding the microalgae-wastewater interactions on a large-scale (Gotaas et al., 1954).

\section{Factors Leading to Microalgae Wastewater Treatment Development}

The postwar economic boom caused a surge in scientific research throughout the world (Soeder, 1986). During this time, three significant factors greatly influenced the development of microalgae wastewater treatment systems: fear of food insecurity, the housing boom, and the rise of environmentalism.

After World War II (WWII), there was the growing fear of a 'Malthusian catastrophe,' or a major food shortage caused by the exponential growth of the human population. This food insecurity was predicted to lead to widespread famine across the globe in the years to follow (Belasco, 1997). Estimates from the United Nations at the time suggested that half of the world was already hungry or malnourished and that food production would need to be increased by $25-35 \%$ in the next 25 years to keep up with the growing population (FAO, 1947). Many countries began to devote research efforts to 
identify ways to increase agricultural productive. This was the beginning of the Green Revolution (Evenson \& Gollin, 2003).

The second factor that prompted the development of microalgae wastewater treatment research was the United States (US) housing boom: a direct result of 12 million service members returning home from war. Much of the development during this era went into constructing new houses in suburbs. Additional federal mortgages and housing projects helped to promote this growth and allowed many who could otherwise not afford a new home to finally do so. Between 1917 and 1956, the number of households increased by $167 \%$ as a direct result. Of these houses, $80 \%$ of non-rural houses had water and sewage systems (Doan, 1997). This large increase in sewage producing facilities led to increased effort to find more efficient methods of treating wastewater (Council, 2002).

The last factor leading to research in microalgae wastewater treatment was the growth of the environmentalist movement. At this time, the US government, and parts of the private sector, became concerned about resource utilization, and subsequently conservation, to meet the demands placed on them by the growing population (Gibboney, 1949). This push, in combination with the publication of $A$ Sand County Almanac (Leopold, 1989) and Silent Spring (Carson, 2002) led to concern over the environmental effects of human waste and pollution. The growing need to prevent harmful material from reaching the environment was steadily becoming an issue that the majority were concerned about.

These factors led the US to make sizable investments in non-military projects as an effort to increase the production of resources (Rossiter, 1985). This funding spurred interest in new areas of engineering and science: one such area being the mass cultivation of microalgae, particularly for production of food and treatment of wastewater. 


\section{Mass Microalgae Cultivation}

Experiments into the mass cultivation of microalgae began in the late 1940's and quickly publicized microalgae as the food source that could end world hunger and support the ever-growing population. Early experiments confirmed the benefits of microalgae over traditional crops: fast growth rate, high protein content, and the ability to use non-arable resources for growth (Belasco, 1997; Geoghegan, 1951; Oswald, 1962). In 1948, the Carnegie Institution of Washington funded researchers in Stanford, California to study the mass production of microalgae Chlorella. This research was followed by the first microalgae pilot plant (Figure 1) at the Massachusetts Institute of Technology in 1951 (Burlew, 1953) and continued by other major research institutions across the US and other populous countries.

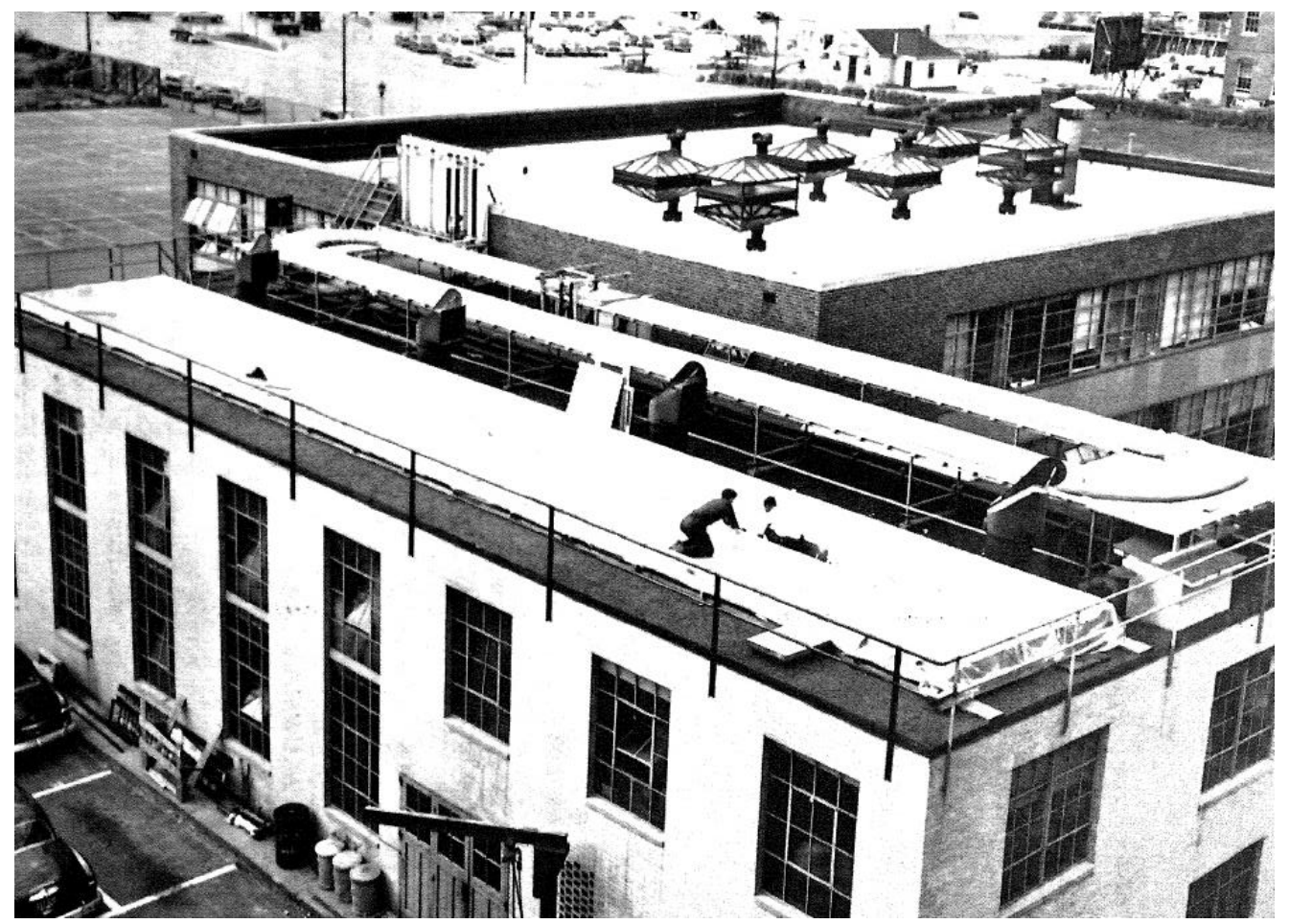

Figure 1: First Large-Scale Microalgae Production Pilot Plant at MIT (1951)

This system, funded by the Carnegie Institute for Science, was part of a large research project into using microalgae for food. It was the first study of its kind and paved the way for future mass algae culturing projects.

Image credit: Carnegie Institution for Science (Burlew, 1953). 
Growth systems for microalgae mass cultures were developed throughout the 1950's and consisted of two prominent designs that still remain in use today. These desigs were the closed photobioreactors (Cook, 1953) and open pond systems (Borowitzka \& Moheimani, 2013; Myers, 1956).

Closed photobioreactors were biological growth systems that utilized transparent materials to grow microalgae within, while minimizing contact from the outside world. They were often tubular in shape to maximize the surface area to volume ratio such that microalgae cells could get ample light. These systems offered excellent control over microalgae in use since they could maintain cultures in a sterile environment, but were expensive to build (Ugwu et al., 2008).

Open ponds were human-made bodies of water that were not protected from their environment. They were often little more than a hole in the ground with mechanisms to keep the culture mixed and suspended. While simpler and cheaper to construct than photobioreactors, open ponds lacked the control over conditions that closed systems offered (Borowitzka \& Moheimani, 2013. Figure 2 shows examples of these two types of systems. 


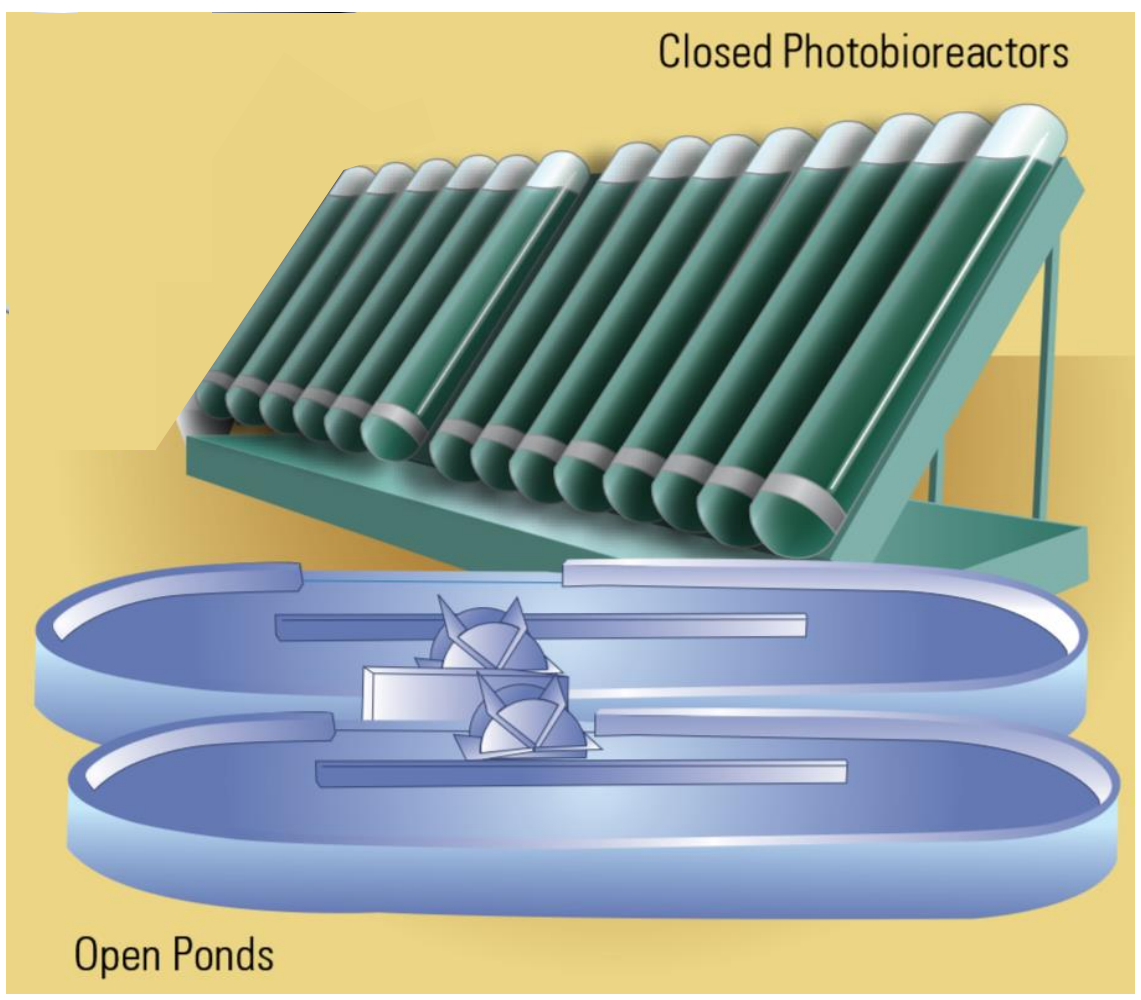

Figure 2: Closed Photobioreactors and Open Pond Systems for Growing Microalgae Closed photobioreactors are show as tubular vessels pitched at an incline to maximize light exposure. Open ponds are represented by two High-Rate Algal Ponds.

Image credit: U.S. Department of Energy (Ferrell \& Sarisky-Reed, 2010).

\section{Early Microalgae Wastewater Treatment Research}

Early studies of microalgae on wastewater were done to test their ability to aerate (Oswald et al., 1953; Oswald \& Gotaas, 1957) and treat (Levin \& Shapiro, 1965)

wastewater. Most of this research was performed by William J Oswald and his fellow researchers at the University of California, Berkeley (Lundquist et al., 2010). Specialized open pond systems to grow microalgae for wastewater treatment were developed and dubbed High-Rate Algal Ponds (HRAPs) (Oswald \& Golueke, 1960). The design of these systems was based on the observational growth of microalgae growing in natural pond systems as well as wastewater stabilization ponds (Oswald et al., 1957). Researches also began to look into wastewater-grown microalgae as a potential food source. The idea of 
combining wastewater treatment and food production using microalgae was briefly studied, but abandoned for a variety of reasons (Cook, 1962; Hintz et al., 1966; Lubitz, 1963). Additionally, research into the use of wastewater-grown microalgae for energy production started with the use of microalgae as a feedstock for methane production (Golueke \& Oswald, 1959; Golueke \& Oswald, 1963b; Meier, 1955) as well as oxygen generators for biochemical fuel cells (Berk \& Canfield, 1964; Lewis, 1966). While low energy costs prompted the abonnement of these ideas, they did provide a fundamental understanding to renewable energy production for researchers in the decades later.

By the mid-1960's, the Green Revolution dismissed the need for novel food sources from microalgae while the development of birth control helped curb unchecked population growth (Belasco, 1997). Attention soon became focused on a stronger perceived threat: the Soviet Union (USSR). Once again, microalgae would come up as an important research topic for waste treatment.

\section{Microalgae Waste Treatment in Life Support Systems}

With the increasing threat of nuclear war after the end of WWII, the US and USSR began a nuclear arms race. During this conflict, the need for methods to sustain humans in controlled environments, like nuclear submarines (Hannan et al., 1963; Leonard, 1960) and space capsules (Golueke et al., 1959; Myers, 1964) became cumbersome engineering challenges. Microalgae showed the potential to close the loop for life-support systems.

These environmental control systems (later named controlled ecological lifesupport systems [CELSS]) would require constant recycling of waste to regenerate needed supplies for days, months, or potentially years at a time (Oswald et al., 1965). Methods to 
complement Human metabolic waste production identified microalgae in multiple aspects of life-support. These were the air regeneration properties of microalgae (i.e., scrubbing carbon dioxide from the air while replenishing oxygen to cabin [Figure 3]) (Miller \& Ward, 1966; Myers, 1954), nutritional properties to feed crew members of the vessel (Casey \& Lubitz, 1963), and water treatment abilities (Brown et al., 1964; Lynch et al., 1964; Ward \& Wilks, 1963).



\section{Figure 3: Testing the Oxygen Regeneration Abilities of Microalgae}

This project, contracted to the Bioastronautics Section of the Boeing Company, was an effort to see if largescale microalgae cultures could maintain oxygen supply for humans in space. Image credit: U.S. Navy Aerospace Medical Research Labs (Bovee et al., 1962).

Implementation of this microalgae waste treatment system in the US took the form of a semi-continuous photobioreactor dubbed the 'Algatron' (Aronowsky, 2017; Munns \& Nickelsen, 2017; Shelef et al., 1970). Early tests of this system with mice showed that it was successful in acting as a photosynthetic gas exchanger over a long duration (Krauss, 1966; Myers, 1960). Later experimentation showed microalgae could be grown on excrement 
from mice as the main nutrient source (Golueke \& Oswald, 1963a). Additional studies examined these systems for their ability to treat human waste and potential implementation of such systems in spacecraft (Figure 4) to replace fecal bags (Golueke \& Oswald, 1967; Golueke et al., 1964). Microalgae strain C. pyrenoidosa TX 71105, now classified as C. sorokiniana UTEX 1230 (Shihira \& Krauss, 1965; Starr \& Zeikus, 1993), showed great promise in use for CELSS and was used almost exclusively by NASA due to its high growth rate, heat tolerance, and ability to grow on a variety of substrates (Sorokin \& Myers, 1953). This strain later became a popular organism for studying microalgae wastewater treatment.

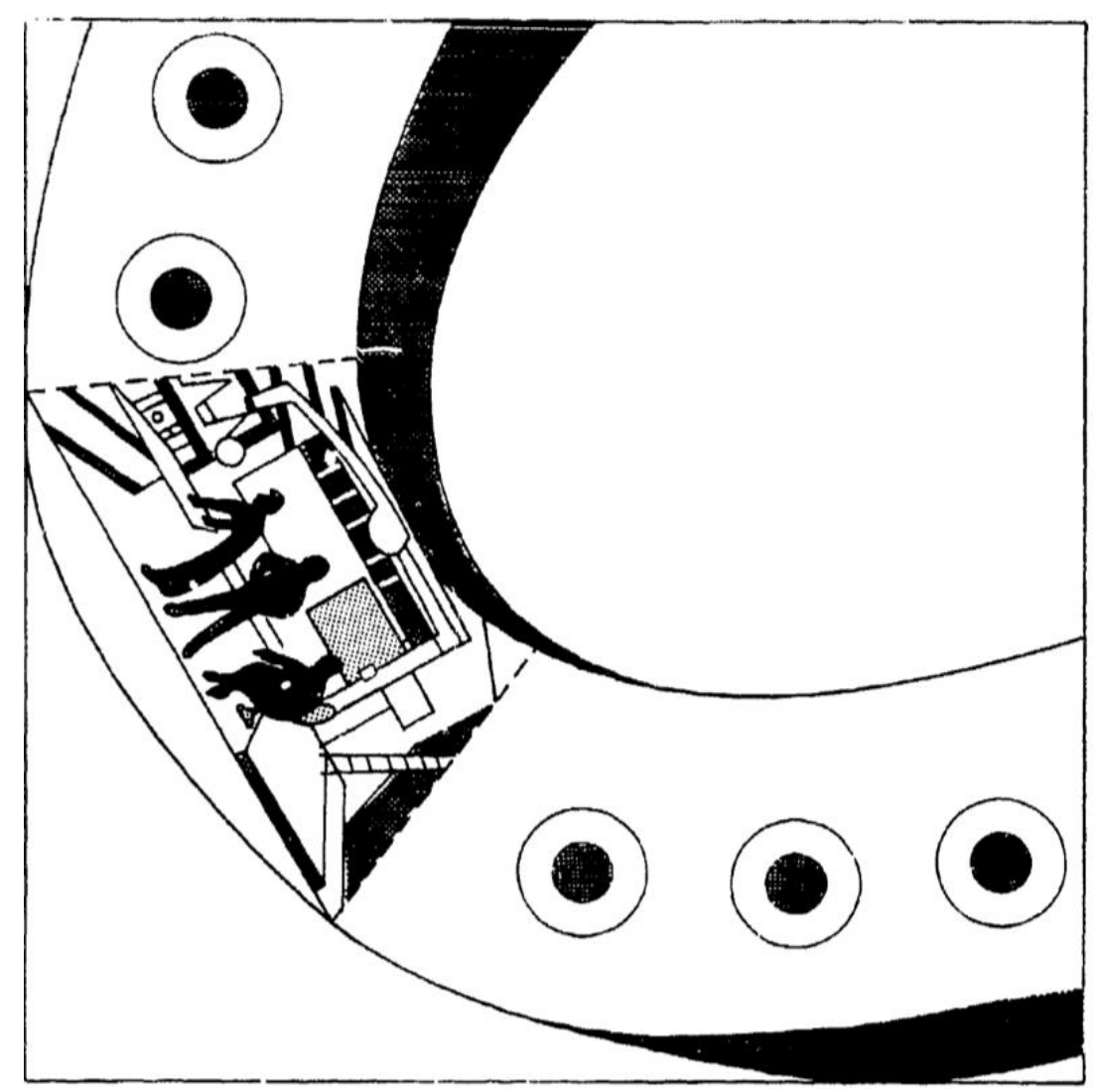

Figure 4: Artist's Conception of Incorporation of Algatrons into a Space Station Algatrons (white circles with the black circle inside them) would face the sun and concentrate light onto the algae through a cone-shaped reflective chamber. Such systems would be feed with human waste for growth and aid in air regeneration for a crew.

Image credit: Air Force Research Laboratories, United States Airforce (Shelef et al., 1966). 
The USSR also experimented with the use of microalgae for air regeneration (Kirensky et al., 1971; Kirensky et al., 1968) as well as for food and waste removal (Soeder, 1986). In the 1970's, experiments using the CELSS Bios-3 showed that humans could survive in closed-environments with plants and microalgae for water, air, and partial nutrient regeneration of human waste through biological systems (Gitelson et al., 1989; Salisbury et al., 1997).

While microalgae life-support systems were constructed and tested on Earth, the idea of using them for submarines and spacecraft never took-off. These systems were not as reliable or robust as the chemical and physical processes later used by both the US and USSR (Aronowsky, 2017). As the space race died down during the early 1970's, research continued into using microalgae in wastewater treatment, but geared towards utilization on the municipal scale (Soeder \& Binsack, 1979). Further concern of the environmental effects of human-made pollution on the oceans primary producers, phytoplankton, prompted new areas of research and methods to use microalgae to treat waste.

\section{Oceanography and Aquaculture}

By the early 1970s, the environmentalist movement had grown considerably, and political pressure on the US government warranted studies of the impact and reduction of ocean pollution (Dunlap \& Mertig, 2013). Researchers started analyzing different aspects of water quality, including the impact of wastewater and other organic pollutants on phytoplankton (Edmondson, 1970; Eppley et al., 1976; Greene et al., 1975; Palmer, 1969). During the same time, the aquaculture industry saw rapid infrastructural advancements due to the development of new materials like polyvinyl chloride (PVC) for plumbing 
equipment and fiberglass for tanks (Nash, 2011). These new materials allowed more control over natural systems and enabled small-scale replication of larger environmental systems. The Woods Hole Oceanographic Institution began studying this intersection of pollution and aquaculture by using wastewater to grow phytoplankton for combined aquaculture and wastewater treatment (Dunstan \& Menzel, 1971; Goldman \& Stanley, 1974; Ryther et al., 1972; Ryther et al., 1975).

Researchers at the Smithsonian Institute's Marine Systems Laboratory began developing microcosms and mesocosms of water ecosystems for to further research the human impact on the ocean (Adey, 2013). One researcher, Dr. Walter Adey, developed a system to remove or "scrub" key nutrients from the water using "turfs" of macro and microalgae. These photosynthetic organisms would replenish the system with cleaned, oxygenated water (Figure 5). Dubbed the Algae Turf Scrubber (ATFTM )(Adey, 1982), this devices became a popular tool for scientists, aquaculturists, and hobbyist (Adey \& Loveland, 2007) before later being considered to be a powerful tool for wastewater treatment (Craggs et al., 1996; Higgins \& Kendall, 2012; Mulbry et al., 2008).

While research into the environmental impacts of human activity on the oceans took place throughout the 1970's, other political pressures opened up a new avenue of research into microalgae wastewater treatment. 


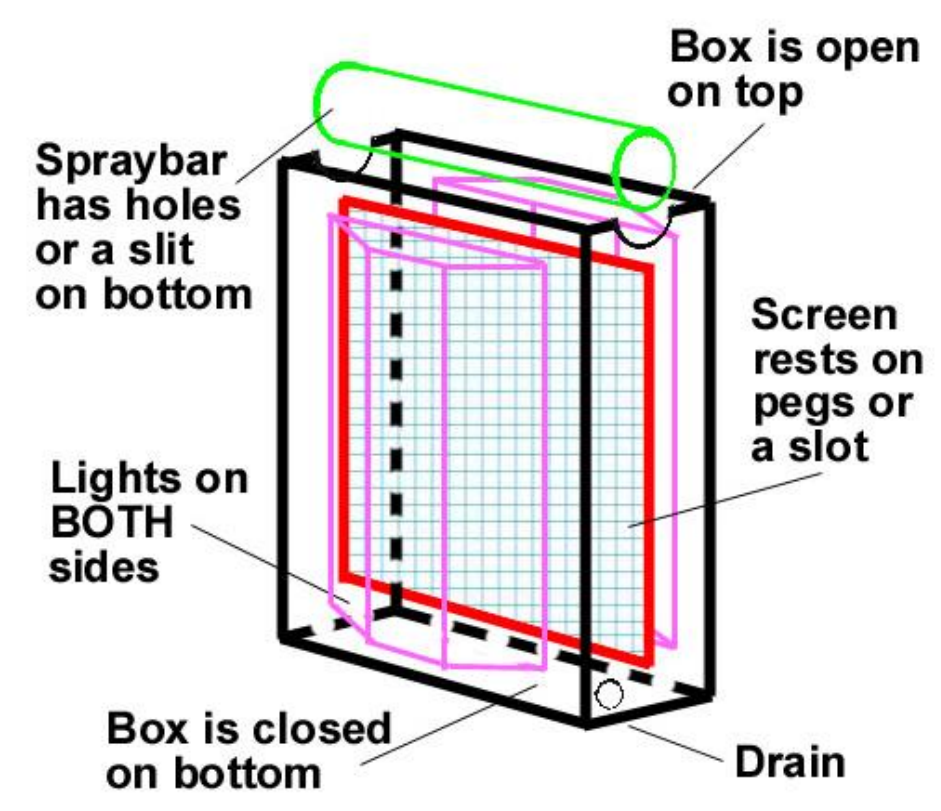

Figure 5: Algae Turf Scrubber Design

Such system sprays water from the top of a screen where algal biofilms form. A large light is placed on the front to allow the growth and nutrient removal by such organisms. Clean, oxygenated water then then leaves through the drain (SantaMonica, 2008).

\section{Energy Crises and the Aquatic Species Program}

The 1970's was hit with two waves of energy crises: the first in 1973 and second in 1979 (Figure 6). Both of these crises were caused by political conflicts in oil producing countries (Deffeyes, 2006). As a result, pressure was placed on the US government to identify alternative energy sources; one such source being microalgae. Early studies of microalgae included wastewater grown microalgae for methane generation (Benemann et al., 1977a; Benemann et al., 1977b; Uziel, 1978) as well as direct hydrogen production from microalgae (Benemann \& Weare, 1974; Hallenbeck \& Benemann, 2002). By 1978, US president Jimmy Carter had formally developed a microalgae research program dubbed the Aquatic Species Program (ASP). The primary goal of this program was to produce fuels from microalgae while utilizing waste carbon dioxide from coal-fired power plants. Initially, the project geared toward growing microalgae for hydrogen, methane, and ethanol 
production, but quickly shifted gears to growing microalgae for lipids to be used for biodiesel production (Sheehan et al., 1998).

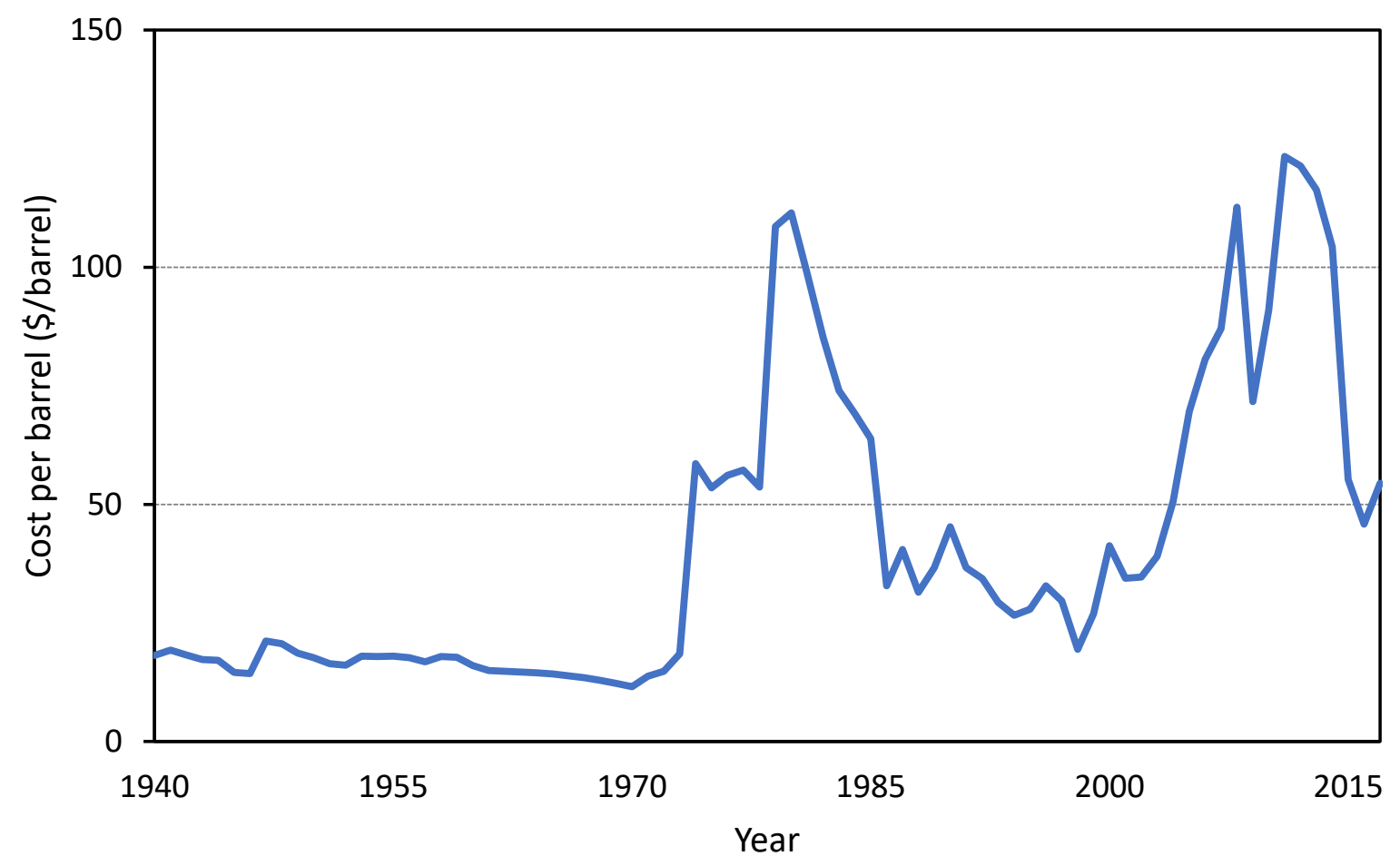

Figure 6: US Oil Prices in 2017 Adjusted Inflation Dollar

The energy crisis throughout the 1970's cause spikes in the cost of oil in 1973 and 1979. Another energy crisis was seen in the 2000's, beginning in 2003 and peaking in 2008 before returning to pre-crisis levels in 2016. Data compiled from 1940-1944 US Average, 1945-1983 Arabian Light, 1984-2017 Brent Dated (BP, 2017).

The project was split into laboratory studies and outdoor studies/system analysis. The laboratory studies consisted of collecting, screening, and characterizing microalgae strains as well as developing strains through the study of biochemistry and physiology of lipid production; this later shifted towards the genetic engineering of microalgae. Outdoor studies and system analysis originally consisted of assessing microalgae production for combined wastewater treatment and biomass production but switched to growing microalgae purely for lipids. This involved constructing and testing both small pond $(<100$ 
$\left.\mathrm{m}^{3}\right)$ and large pond $\left(1000 \mathrm{~m}^{3}\right)$ studies as well as developing resource assessment of these systems (Sheehan et al., 1998). The landmarks of this study are summarized in Figure 7.

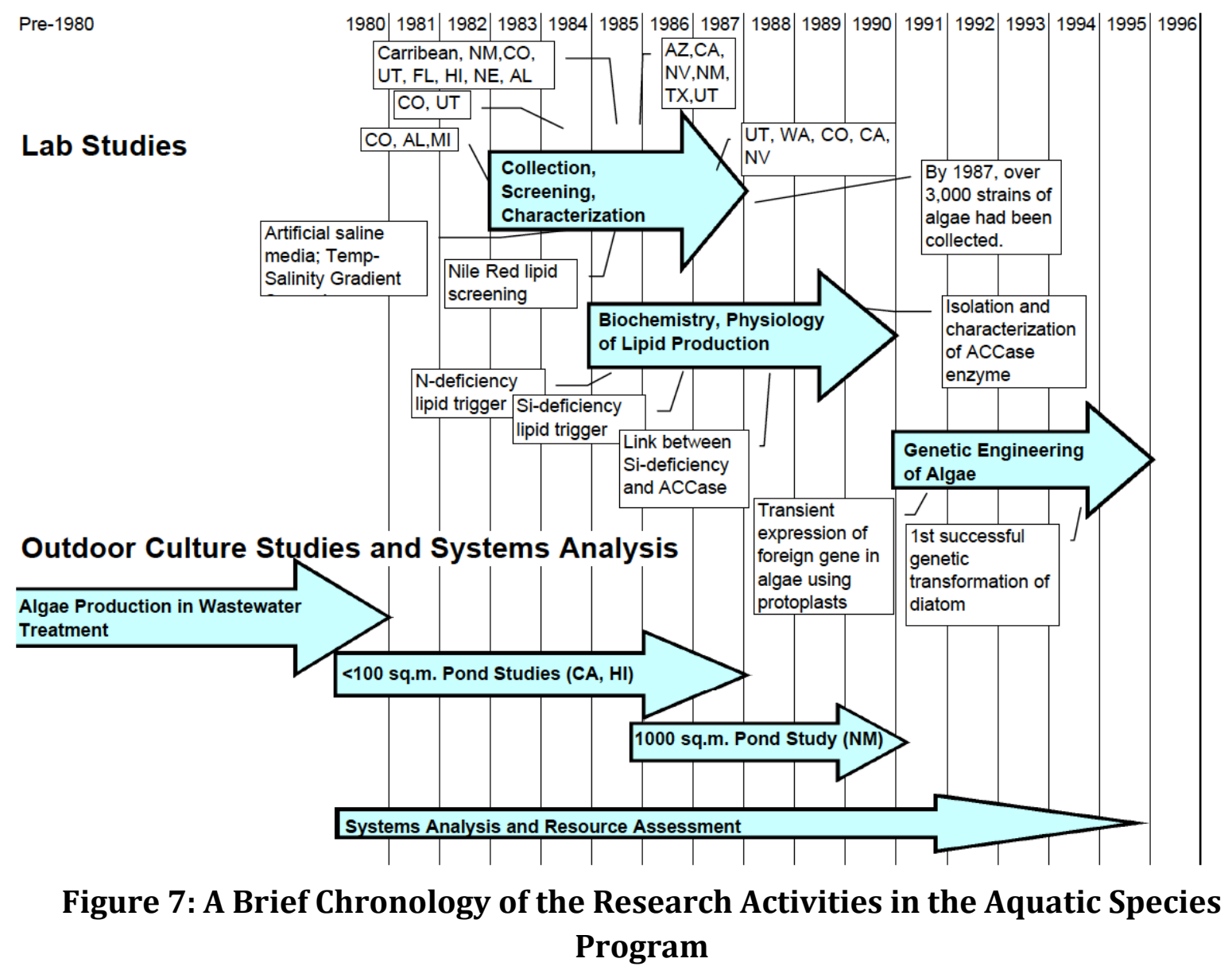

Studies in the ASP investigated lab studies and outdoor culture studies and system analysis. This study lasted from the late 1970's to 1996.

Image Credit: U.S. Department of Energy (Sheehan et al., 1998).

The ASP lasted for over 20 years and was fundamental to the current understanding of microalgae biofuel production. The results of this project included the screening and characterization over 3,000 new microalgae strains, improvement of high-throughput screening methods to identify productive microalgae, identification the metabolic role of Acetyl-CoA carboxylase in lipid production and methods to induce lipid accumulation in microalgae (through nitrogen and silica deficiency), development of tools for genetically 
engineering microalgae, and creating methods for scaling up the growth of microalgae for biofuel production (Sheehan et al., 1998).

At the end of the project, two major conclusions were reached: no apparent engineering or economic issues were hindering the feasibility of large-scale microalgae cultivation and microalgae biomass and lipid productivities were below their theoretical potential. The project researchers suggested that the only near- to mid-term application of microalgae for biofuel production would be to integrate it with wastewater treatment. Future work would need to increase the photosynthetic efficiency and lipid conversion in microalgae through genetic engineering to make it even more economical for biofuel production (Sheehan et al., 1998). This conclusion was substantial, as it promoted an economical solution to large-scale microalgae production through microalgae wastewater treatment.

As a result of this program, multiple HRAPs for treating wastewater were constructed (Figure 8) in California (Benemann et al., 1980; Oswald, 1976; Oswald \& Golueke, 1960) and Florida (Lincoln \& Hill, 1980). Also, the first fully functional combined wastewater treatment and biomass production pond system was constructed in Singapore (Taiganides, 1982). Since then, other microalgae wastewater treatment systems have been implemented throughout the world utilizing the HRAP system (Abdel-Raouf et al., 2012). 


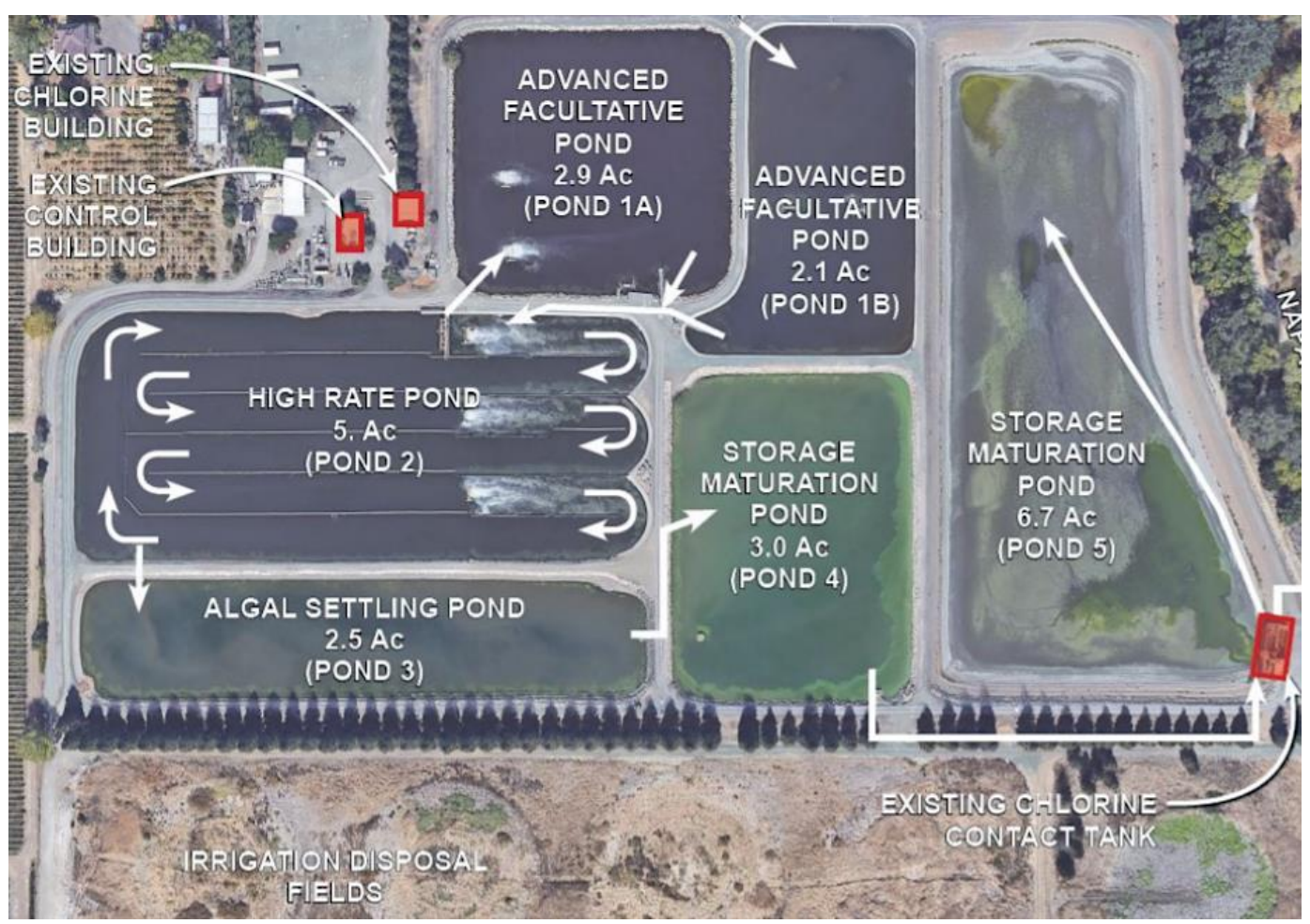

Figure 8: The St. Helena Wastewater Treatment Facility in Operation, ca. 2016

This facility used an HRAP to treat municipal waste through an innovative process developed by Professor William J. Oswald.

Image credit: City of St. Helena (Hulburd, 2016).

After the energy crisis of the 1970's, the perceived need for alternative energy sources died down as the price of oil stabilized. Governmental investment in biofuel research slowly decreased and interest in microalgae for fuel subsided as a result. The next big investment in microalgae wastewater treatment came once again due to energy shortages.

\section{Energy Crisis of the 2000's}

Most of the research into microalgae wastewater treatment during the turn of the century became coupled with biofuel production due to the volatility in oil prices (Sheehan et al., 1998). In the early 2000's, the world faced another energy crisis, driven again by 
rising oil prices. This crisis was due to the geopolitical conflicts in the middle east and became further aggravated by Hurricane Katrina in 2005, followed by the start Great Recession from the collapse of the housing market in 2007 (Grusky et al., 2011). During this time, oil prices increased by over $600 \%$ in just under ten years (Figure 6). The instability in the cost of oil, along with the well documented environmental dangers (such as global warming) associated with petroleum fuels led the to a public push for the development of alternative energy sources.

This US government quickly responded with the Energy Independence and Security Act of 2007, which promoted the use of renewable energy and set new fuel economy standards in cars (Gallinaro, 2014). Following that, additional investment in microalgae biofuels came from the American Recovery and Reinvestment Act of 2009, the Department of Energy (DOE), state funding through universities and labratories, and private investments (Pienkos \& Darzins, 2009). The Air Force Office of Scientific Research started the algal biojet program to produce jet fuel from microalgae.

A sudden boom in microalgae related fuel endeavors led to the development of multiple microalgae biofuel startups like Solazyme (now TerraVia) and Sapphire Energy (Mascarelli, 2009). The microalgae-based research produced during this time was summarized and outlined in the 2010 National Algal Biofuels Technology Roadmap published by the DOE (Ferrell \& Sarisky-Reed, 2010). This publication also acted as a guide for researchers in their efforts to reduce the cost of algae biofuels.

Many notable projects were developed during that time to show the potential of wastewater grown microalgae for biofuel production. One of which was NASA's Offshore Membrane Enclosures for Growing Algae (OMEGA) project (Figure 9). This project utilized 
microalgae grown in semi-permeable membranes to treat wastewater and release clean water back into the ocean (Trent et al., 2012). Additionally, a small-scale study preformed at Cal Poly San Luis Obispo showed the ability of native microalgae to grow in dairy and municipal wastewater as a means to decrease biofuel production costs (Woertz et al., 2009). Efforts to scale up this microalgae-wastewater processes were also demonstrated in large-scale HRAPs (Craggs et al., 2012).

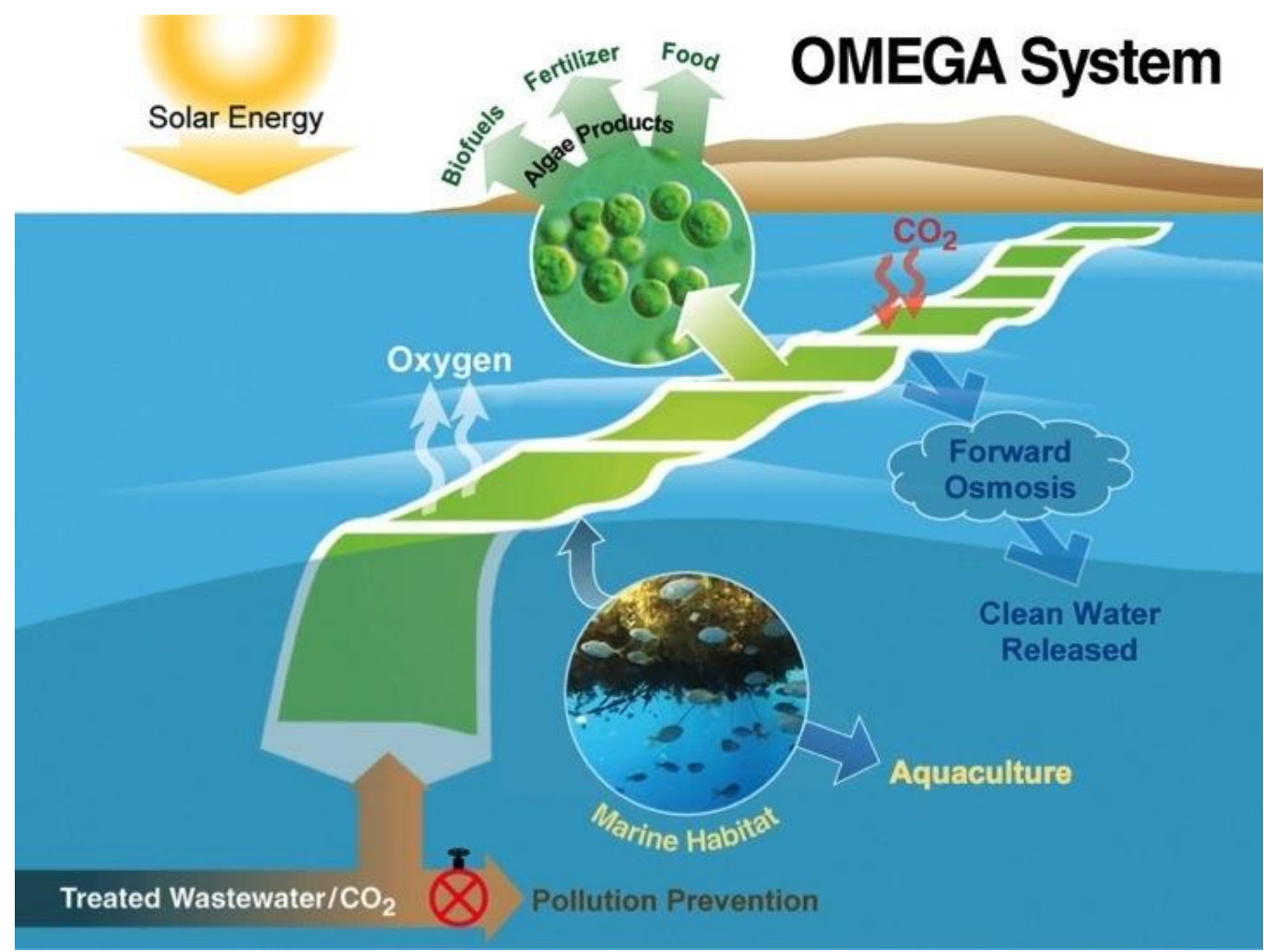

Figure 9: NASA's OMEGA Project

A floating photobioreactor system to grow microalgae on wastewater as a means to treat waste and produce valuable biomass. The semi-permeable membrane allows for the diffusion of carbon dioxide (CO2) in and oxygen out while releasing clean waster through forward osmosis. The reactor would provide a habitat for marine life and could be combined with aquaculture production systems.

Image Credit: NASA (NASA, 2012).

\section{Microalgae Wastewater Treatment Today}

Since then, international efforts have backed in-depth research into the development of microalgae wastewater treatment. These efforts include utilizing different 
types of wastewater (Aslan \& Kapdan, 2006; Garcia et al., 2000; Wang et al., 2010) as well as integrating them with immobilized systems (Mallick, 2002; Ruiz-Marin et al., 2010; Zhang et al., 2008). Most of this research has focused on the use of microalgae grown on wastewater to later be used as a biofuel (Craggs et al., 2012; Li et al., 2011; Park et al., 2011) as suggested by the ASP in 1998 (Sheehan et al., 1998) and confirmed by more recent assessments (Higgins \& Kendall, 2012; Lundquist et al., 2010; Sander \& Murthy, 2010). The continued interest in microalgae comes from a push for environmental sustainability, fuel security, and combatting climate change.

\section{Conclusion}

The use of microalgae for wastewater treatment has long been considered a viable method of treating waste streams while producing high-value microalgae biomass. Research into the use of microalgae for waste treatment systems has spanned over a century and has been closely tied to political and economic events. Currently, environmental consciousness and fuel security are driving the need for research and development of microalgae wastewater treatment. While large-scale treatment facilities have not yet been widely adopted, it is expected that a combination of technological advancement, as well as sociopolitical pressure, may yield to the development of these facilities in the near future. 


\section{References}

Abbott, W. 1948. Oxygen production in water by photosynthesis. Sewage Works Journal, $\mathbf{2 0}(3), 538-541$.

Abdel-Raouf, N., Al-Homaidan, A., Ibraheem, I. 2012. Microalgae and wastewater treatment. Saudi Journal of Biological Sciences, 19(3), 257-275.

Adey, W.H. 1982. Algal Turf Scrubber, (Ed.) USPTO, Smithsonian Institute United States.

Adey, W.H. 2013. Microcosms and Mesocosms - Restoring Earth's Ecosystems, Vol. 2018.

Adey, W.H., Loveland, K. 2007. Dynamic Aquaria: Building and Restoring Living Ecosystems. 3 ed. Elsevier, Burlington, MA.

Agersborg, H., Hatfield, W.D. 1929. The biology of a sewage treatment plant: A preliminary survey: Decatur, Illinois. Sewage Works Journal, 1(4), 411-424.

Aronowsky, L.V. 2017. Of astronauts and algae: NASA and the dream of multispecies spaceflight. Environmental Humanities, 9(2), 359-377.

Aslan, S., Kapdan, I.K. 2006. Batch kinetics of nitrogen and phosphorus removal from synthetic wastewater by algae. Ecological Engineering, 28(1), 64-70.

Belasco, W. 1997. Algae burgers for a hungry world? The rise and fall of Chlorella cuisine. Technology and Culture, 38(3), 608-634.

Benemann, J., Koopman, B., Weissman, J., Eisenberg, D., Goebel, R. 1980. Development of Microalgae Harvesting and High-Rate Pond Technologies in California. in: Algae Biomass: Production and Use, (Eds.) G. Shelef, C.J. Soeder, Elsevier Science. Amsterdam, pp. 457-499.

Benemann, J.R., Koopman, B., Weissman, J., Oswald, W.J. 1977a. Biomass production and waste recycling with blue-green algae. Microbial Energy Conversion, Göttingen, Germany. Elsevier. pp. 399-412.

Benemann, J.R., Weare, N. 1974. Hydrogen evolution by nitrogen-fixing Anabaena cylindrical cultures. Science, 184(4133), 174-175.

Benemann, J.R., Weissman, J.C., Koopman, B.L., Oswald, W.J. 1977b. Energy production by microbial photosynthesis. Nature, 268(5615), 19.

Berk, R.S., Canfield, J.H. 1964. Bioelectrochemical energy conversion. Applied Microbiology, 12(1), 10-12.

Bischoff, C., Knauff, H. 1883. The petrie sewage disposal system. The Sanitarian (18731904), 11(132), 226.

Borowitzka, M.A., Moheimani, N.R. 2013. Open Pond Culture Systems. in: Algae for Biofuels and Energy, (Eds.) M.A. Borowitzka, N.R. Moheimani, Vol. 5, Springer. Dordrecht Heidelberg New York London pp. 133-152.

Bovee, H., Pilgrim, A., Sun, L., Schubert, J., Eng, T., Benishek, B. 1962. Large Algal Systems. Boeing Company AMRL TDR 62-116.

BP. 2017. BP Statistical Review of World Energy.

Brown, L., Kennedy, M., Tischer, R. 1964. An algal medium produced from human wastes. Developments in Industrial Microbiology, 6, 245-249.

Burlew, J.S. 1953. Algal Culture from Laboratory to Pilot Plant. Carnegie Institution of Washington, Washington, D. C.

Caldwell, D. 1946. Sewage oxidation ponds: performance, operation and design. Sewage Works Journal, 18(3), 433-458.

Carson, R. 2002. Silent spring. Houghton Mifflin Harcourt. 
Casey, R., Lubitz, J. 1963. Algae as food for space travel: a review. Food Technology, 17(11), 48-56.

Cook, B.B. 1962. The nutritive value of waste-grown algae. American Journal of Public Health and the Nations Health, 52(2), 243-251.

Cook, P.M. 1953. Apparatus and Process for The Production of Photosynthetic Microorganisms, Particularly Algae, (Ed.) USPTO, Carnegie Institution of Washington. United States.

Cotton, A. 1910. On the growth of Ulva latissima, L. In water polluted by sewage. Bulletin of Miscellaneous Information (Royal Botanic Gardens, Kew), 1910(1), 15-19.

Council, N.R. 2002. Privatization of water services in the United States: an assessment of issues and experience. National Academies Press.

Craggs, R., Sutherland, D., Campbell, H. 2012. Hectare-scale demonstration of high rate algal ponds for enhanced wastewater treatment and biofuel production. Journal of Applied Phycology, 24(3), 329-337.

Craggs, R.J., Adey, W.H., Jenson, K.R., John, M.S.S., Green, F.B., Oswald, W.J. 1996. Phosphorus removal from wastewater using an algal turf scrubber. Water Science and Technology, 33(7), 191-198.

Deffeyes, K.S. 2006. Beyond Oil: The View from Hubbert's Peak. Hill and Wang, New York.

Doan, M.C. 1997. American housing production, 1880-2000: A concise history. University Press of America.

Dunlap, R.E., Mertig, A.G. 2013. American Environmentalism: The US Environmental Movement, 1970-1990. Taylor \& Francis, New York, NY.

Dunstan, W.M., Menzel, D.W. 1971. Continuous Cultures of Natural Populations of Phytoplankton in Dilute Treated Sewage Effluent. Limnology and Oceanography, 16(4), 623-632.

Edmondson, W. 1970. Phosphorus, nitrogen, and algae in Lake Washington after diversion of sewage. Science, 169(3946), 690-691.

Eppley, R., Renger, E., Williams, P. 1976. Chlorine reactions with seawater constituents and the inhibition of photosynthesis of natural marine phytoplankton. Estuarine and Coastal Marine Science, 4(2), 147-161.

Espinosa, A. 1948. The role of algae in waste treatment. Public Works, 79, 36.

Evenson, R.E., Gollin, D. 2003. Assessing the impact of the Green Revolution, 1960 to 2000. science, $\mathbf{3 0 0}(5620)$, 758-762.

FA0. 1947. The State of Food and Agriculture: 1947. Food and Agriculture Organization of the United Nations (FAO).

Ferrell, J., Sarisky-Reed, V. 2010. National Algal Biofuels Technology Roadmap. U.S. Department of Energy, Office of Energy Efficiency and Renewable Energy, Biomass Program.

Frankland, P. 1897. The bacterial purification of water. Minutes of the Proceedings of The Institution of Civil Engineers, 127(1897), 83-111.

Gallinaro, D. 2014. American funding for biofuel/biorefinery research \& development. Environmental Biotechnology, 10.

Garcia, J., Mujeriego, R., Hernandez-Marine, M. 2000. High rate algal pond operating strategies for urban wastewater nitrogen removal. Journal of Applied Phycology, 12(3-5), 331-339.

Geoghegan, M. 1951. Unicellular algae as a source of food. Nature, 168(4271), 426. 
Gibboney, C.N. 1949. The United Nations scientific conference for the conservation and utilization of resources. Science, 110(2869), 675-678.

Gitelson, I., Terskov, I., Kovrov, B., Lisovskii, G., Okladnikov, Y.N., Sid'Ko, F.Y., Trubachev, I., Shilenko, M., Alekseev, S., Pan'kova, I. 1989. Long-term experiments on man's stay in biological life-support system. Advances in Space Research, 9(8), 65-71.

Goldman, J., Stanley, H. 1974. Relative growth of different species of marine algae in wastewater-seawater mixtures. Marine Biology, 28(1), 17-25.

Golueke, C.G., Oswald, W.J. 1959. Biological conversion of light energy to the chemical energy of methane. Applied Microbiology, 7(4), 219-227.

Golueke, C.G., Oswald, W.J. 1963a. Closing an ecological system consisting of a mammal, algae, and non-photosynthetic microorganisms. The American Biology Teacher, 25(7), 522-528.

Golueke, C.G., Oswald, W.J. 1963b. Power from solar energy-Via algae-produced methane. Solar Energy, 7(3), 86-92.

Golueke, C.G., Oswald, W.J. 1967. The spin-inertia culture system in waste treatment in closed systems. The Closed Life-Support System, 134, 163.

Golueke, C.G., Oswald, W.J., Gee, H.K. 1964. First Technical Report. Air Force Cambridge Research Laboratories, Office of Aerospace Research, United States Air Force, Bedford, Massachusetts.

Golueke, C.G., Oswald, W.J., McGauhey, P.H. 1959. The biological control of enclosed environments. Sewage and Industrial Wastes, 31(10), 1125-1142.

Gotaas, H.B., Oswald, W.J., Ludwig, H.F. 1954. Photosynthetic reclamation of organic wastes. The Scientific Monthly, 79(6), 368-378.

Greene, J.C., Miller, W.E., Shiroyama, T., Maloney, T.E. 1975. Utilization of algal assays to assess the effects of municipal, industrial, and agricultural wastewater effluents upon phytoplankton production in the Snake River system. Water, Air, and Soil Pollution, 4(3-4), 415-434.

Grusky, D.B., Western, B., Wimer, C. 2011. The Great Recession. Russell Sage Foundation, New York, NY.

Hallenbeck, P.C., Benemann, J.R. 2002. Biological hydrogen production; fundamentals and limiting processes. International Journal of Hydrogen Energy, 27(11-12), 1185-1193.

Hannan, P., Shuler, R., Patouillet, C. 1963. A Study of the Feasibility of Oxygen Production by Algae for Nuclear Submarines. Naval Research Lab, Washington DC.

Higgins, B.T., Kendall, A. 2012. Life cycle environmental and cost impacts of using an algal turf scrubber to treat dairy wastewater. Journal of Industrial Ecology, 16(3), 436447.

Hintz, H., Heitman Jr, H., Weir, W., Torell, D., Meyer, J. 1966. Nutritive value of algae grown on sewage. Journal of Animal Science, 25(3), 675-681.

Hulburd, G. 2016. Report for City of St. Helena - Wastewater Treatment and Reclamation Plant Improvements Draft Feasibility Study. City of St. Helena.

Kirensky, L., Gitelson, I., Terskov, I., Kovrov, B., Lisovsky, G., Okladnikov, Y.N. 1971. Theoretical and experimental decisions in the creation of an artificial ecosystem for human life support in space. Life Sciences and Space Research, 9, 75-80.

Kirensky, L., Terskov, I., Gitelson, I., Lisovsky, G., Kovrov, B., Okladnikov, Y.N. 1968. Experimental biological life support system. II. Gas exchange between man and 
microalgae culture in a 30-day experiment. Life Sciences and Space Research, 6, 3740.

Krauss, R.W. 1966. The physiology and biochemistry of algae, with special reference to continuous-culture techniques for Chlorella. Bioregenerative Systems, Washington, D.C. NASA. pp. 97-109.

Leonard, J.M. 1960. Algae and submarine habitability. Developments in Industrial Microbiology, Boston, MA. Springer. pp. 26-32.

Leopold, A. 1989. A Sand County almanac, and sketches here and there. Outdoor Essays \& Reflections.

Levin, G.V., Shapiro, J. 1965. Metabolic uptake of phosphorus by wastewater organisms. Journal (Water Pollution Control Federation), 37(6), 800-821.

Lewis, K. 1966. Symposium on bioelectrochemistry of microorganisms. IV. Biochemical fuel cells. Bacteriological Reviews, $\mathbf{3 0}(1), 101$.

Li, Y., Zhou, W., Hu, B., Min, M., Chen, P., Ruan, R.R. 2011. Integration of algae cultivation as biodiesel production feedstock with municipal wastewater treatment: strains screening and significance evaluation of environmental factors. Bioresource Technology, 102(23), 10861-10867.

Lincoln, E., Hill, D. 1980. An Integrated Microalgae System. in: Algae Biomass: Production and Use, (Eds.) G. Shelef, C.J. Soeder, Elsevier. Amsterdam.

Lubitz, J.A. 1963. The protein quality, digestibility, and composition of algae, Chlorella 71105. Journal of Food Science, 28(2), 229-232.

Lundquist, T.J., Woertz, I.C., Quinn, N., Benemann, J.R. 2010. A realistic technology and engineering assessment of algae biofuel production. Energy Biosciences Institute, 1.

Lynch, V., Ammann, E., Godding, R. 1964. Urine as a Nitrogen Source for Photosynthetic Gas Exchangers. Aerospace Medicine, 35, 1067-1071.

Mallick, N. 2002. Biotechnological potential of immobilized algae for wastewater N, P and metal removal: a review. Biometals, 15(4), 377-390.

Mascarelli, A.L. 2009. Gold rush for algae. Nature, 461(24), 460-461.

Meier, R. 1955. Biological cycles in the transformation of solar energy into useful fuels. Solar Energy Research, 23, 179-183.

Miller, R.L., Ward, C.H. 1966. Algal Bioregenerative Systems. in: Atmosphere in Space Cabins and Closed Environments, (Ed.) K. Kammermeyer, Springer. Boston, MA, pp. 186-222.

Mulbry, W., Kondrad, S., Pizarro, C., Kebede-Westhead, E. 2008. Treatment of dairy manure effluent using freshwater algae: algal productivity and recovery of manure nutrients using pilot-scale algal turf scrubbers. Bioresource Technology, 99(17), 8137-8142.

Munns, D.P., Nickelsen, K. 2017. To live among the stars: artificial environments in the early space age. History and Technology, 33(3), 272-299.

Myers, J. 1954. Basic remarks on the use of plants as biological gas exchangers in a closed system. The Journal of Aviation Medicine, 25(4), 407-411.

Myers, J. 1964. Use of algae for support of the human in space. Life Sciences and Space Research, 2, 323-336.

Myers, J. 1960. The use of photosynthesis in a closed ecological system. Physics \& Medicine of The Atmosphere \& Space, New York \& London. John Wiley \& Sons Inc. pp. 387-396. Myers, J.E. 1956. Mass Culture of Algae, (Ed.) USPTO. United States.

NASA. 2012. OMEGA Offshore Membrane Enclosures for Growing Algae (Ed.) N.A.a.S.A.A.R. Center, NASA. 
Nash, C.E. 2011. The History of Aquaculture. Wiley-Blackwell, Ames, IA.

Oswald, W., Gotaas, H., Golueke, C., Kellen, W., Gloyna, E., Hermann, E. 1957. Algae in Waste Treatment. Sewage and Industrial Wastes, 29(4), 437-457.

Oswald, W.J. 1962. The coming industry of controlled photosynthesis. American Journal of Public Health and the Nations Health, 52(2), 235-242.

Oswald, W.J. 1976. Experiences with new pond designs in California. Ponds as a Wastewater Treatment Alternative, Austin, TX. University of Texas at Austin. pp. 257-272.

Oswald, W.J., Golueke, C.G. 1960. Biological transformation of solar energy. Advances in Applied Microbiology, 2, 223-262.

Oswald, W.J., Golueke, C.G., Horning, D.0. 1965. Closed ecological systems. Journal of the Sanitary Engineering Division, 91(4), 23-48.

Oswald, W.J., Gotaas, H., Ludwig, H.F., Lynch, V. 1953. Algae symbiosis in oxidation ponds: III. Photosynthetic oxygenation. Sewage and Industrial Wastes, 25(6), 692-705.

Oswald, W.J., Gotaas, H.B. 1957. Photosynthesis in sewage treatment. Transactions of the American Society of Civil Engineers, 122(1), 73-97.

Palmer, C.M. 1969. A composite raiting of algae tolerating organic pollution. Journal of Phycology, 5(1), 78-82.

Park, J., Craggs, R., Shilton, A. 2011. Wastewater treatment high rate algal ponds for biofuel production. Bioresource Technology, 102(1), 35-42.

Pienkos, P.T., Darzins, A. 2009. The promise and challenges of microalgal-derived biofuels. Biofuels, Bioproducts and Biorefining, 3(4), 431-440.

Rossiter, M.W. 1985. Science and public policy since World War II. Osiris Historical Writing on American Science, 1, 273-294.

Ruiz-Marin, A., Mendoza-Espinosa, L.G., Stephenson, T. 2010. Growth and nutrient removal in free and immobilized green algae in batch and semi-continuous cultures treating real wastewater. Bioresource Technology, 101(1), 58-64.

Ryther, J., Dunstan, W., Tenore, K., Huguenin, J. 1972. Controlled eutrophicationincreasing food production from the sea by recycling human wastes. BioScience, 22(3), 144-152.

Ryther, J.H., Goldman, J.C., Gifford, C.E., Huguenin, J.E., Wing, A.S., Clarner, J.P., Williams, L.D., Lapointe, B.E. 1975. Physical models of integrated waste recycling-marine polyculture systems. Aquaculture, 5(2), 163-177.

Salisbury, F.B., Gitelson, J.I., Lisovsky, G.M. 1997. Bios-3: Siberian experiments in bioregenerative life support. BioScience, 47(9), 575-585.

Sander, K., Murthy, G.S. 2010. Life cycle analysis of algae biodiesel. The International Journal of Life Cycle Assessment, 15(7), 704-714.

SantaMonica. 2008. Original Vertical Scrubber Design. Wikimedia Commons.

Sheehan, J., Dunahay, T., Benemann, J., Roessler, P. 1998. A Look Back at the US Department of Energy's Aquatic Species Program: Biodiesel from Algae. National Renewable Energy Laboratory. NREL/TP-580-24190.

Shelef, G., Golueke, C.G., Oswald, W.J., Gee, H.K. 1966. A Study of Fundamental Factors Pertinent to Microbiological Waste Conversion in Control of Isolated Environments: Final Report. Air Force Cambridge Research Laboratories Office of Aerospace Research United States Airforce.

Shelef, G., Oswald, W.J., McGauhey, P. 1970. Algal reactor for life support systems. Journal of the Sanitary Engineering Division, 96(1), 91-110. 
Shihira, I., Krauss, R.W. 1965. Chlorella: Physiology and Taxonomy of Forty-One Isolates. University of Maryland, College Park, Maryland.

Soeder, C. 1986. An Historical Outline of Applied Algology. in: Handbook of Microalgal Mass Culture, (Ed.) A. Richmand, CRC Press, pp. 25-42.

Soeder, C.J., Binsack, R. 1979. Microalgae for food and feed. Archiv für Hydrobiologie Advances in Limnology (Ergebnisse der Limnologie), Neuherberg, Germany. pp. 300.

Sorokin, C., Myers, J. 1953. A high-temperature strain of Chlorella. Science, 117(3039), 330331.

Starr, R.C., Zeikus, J.A. 1993. UTEX-the culture collection of algae at the University of Texas at Austin 1993 list of cultures. Journal of Phycology, 29(s2), 1-106.

Taiganides, E. 1982. Biomass from the treatment of pig wastes. Wissenschaft Umwelt, 4, 256-267.

Trent, J., Wiley, P., Tozzi, S., McKuin, B., Reinsch, S. 2012. Research Spotlight: The future of biofuels: is it in the bag? Biofuels, 3(5), 521-524.

Ugwu, C., Aoyagi, H., Uchiyama, H. 2008. Photobioreactors for mass cultivation of algae. Bioresource Technology, 99(10), 4021-4028.

Uziel, M. 1978. Solar Energy Fixation and Conversion With Algal Bacterial Systems. in: Sanitary Engineering, University of California, Berkeley. Berkeley, CA.

Wang, L., Min, M., Li, Y., Chen, P., Chen, Y., Liu, Y., Wang, Y., Ruan, R. 2010. Cultivation of green algae Chlorella sp. in different wastewaters from municipal wastewater treatment plant. Applied Biochemistry and Biotechnology, 162(4), 1174-1186.

Ward, C., Wilks, S. 1963. Use of algae and other plants in the development of life support systems. The American Biology Teacher, 25(7), 512-521.

Woertz, I., Feffer, A., Lundquist, T., Nelson, Y. 2009. Algae grown on dairy and municipal wastewater for simultaneous nutrient removal and lipid production for biofuel feedstock. Journal of Environmental Engineering, 135(11), 1115-1122.

Zhang, E., Wang, B., Wang, Q., Zhang, S., Zhao, B. 2008. Ammonia-nitrogen and orthophosphate removal by immobilized Scenedesmus sp. isolated from municipal wastewater for potential use in tertiary treatment. Bioresource Technology, 99(9), 3787-3793. 